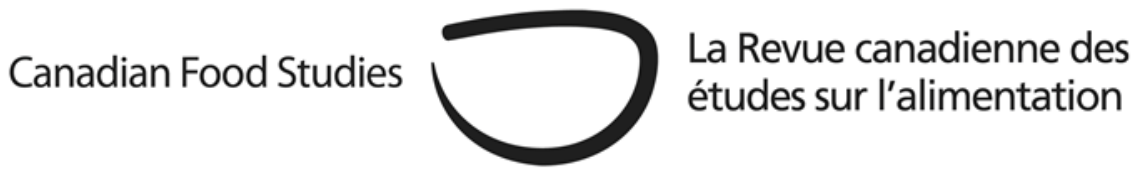

Book Review

\title{
The strawberry squeeze-a review of Wilted: chemicals, pathogens, and the fragile future of the strawberry industry
}

Julie Guthman

Critical Environments: Nature, Science, and Politics/University of California Press, 328 pages

Review by Janette Haase

The picture on the cover of Julie Guthman's latest book Wilted: Pathogens, Chemicals and the Fragile Future of the Strawberry Industry depicts a strawberry made of oil, its tiny seeds visible on the dark blueish black flesh. The leafy top is a yellowish-brown colour, a far cry from the vibrant green that would crown a healthy strawberry. Unfortunately, this is a fitting depiction of the California strawberry industry, plagued by fungal diseases and pests, and propped up by oilbased agricultural chemicals and acres of plastic tarping. The only thing missing from the book's cover picture are the dollar signs, a testament to the profits that greedy industry players have exacted at the expense of the environment and low-wage workers.

Guthman's book draws on extensive, interdisciplinary research, including interviews with growers, farm workers, scientists, and industry, as well as historical accounts and past and present publications. The result is an in-depth account of the development and subsequent entrenchment of an industry that is finding that the chickens do eventually come home to roost. California's strawberry industry began in the mid $19^{\text {th }}$ century and was centered in the warm climate and fertile lands surrounding San Francisco and Los Angeles. Verticillium Wilt, a fungal disease present in all soils, flourished in the monoculture fields and became a significant problem in the 1920's and 1930's, resulting in greatly decreased yields. But two World Wars left the United States with an abundance of toxic chemicals, among them chloropicrin (aka tear gas) and methyl bromide, which had been used as a de-lousing agent. When injected into the soil these two chemicals were found to kill the disease-causing fungi. Add to the mix 1,3 dichloropropene, a cheap and toxic by-product of the oil industry, and yearly widespread soil fumigation became the 'fix' that growers were looking for.

*Corresponding author: janettehaase@gmail.com

DOI: $10.15353 / c f s-r c e a . v 7 i 1.420$ 
The strength of Wilted lies in the detailed way in which Guthman ties together the economic, scientific, social, and environmental developments that have occurred in the strawberry industry, all of which are predicated on the adoption of fumigation as a foundation for successful cultivation. With fumigants acting as insurance against crop loss, plant breeders no longer bred for disease resistance and focussed instead on developing cultivars that were high yielding and productive all year round. Plant breeding is an integral part of the strawberry industry because in the monoculture fields new plants or 'starts' must be planted every year. Genetics become a commodity and proprietary interests mean breeders can charge high prices for their product. As yields increased so did the supply, so marketing interests stepped in to promote the California strawberry as one of nature's healthiest foods. Breeders looked for varieties that shipped well and were durable, further weakening the resilience of their cultivars because, as Guthman explains, there is only so much carbon in an organism and if allocated to one trait, it must detract from another. As the industry grew, profits increased and so too did land rents. An expectation for high profits resulted in downward pressures on labour cost, further marginalizing migrant workers. Over time the industry became dominated by a few vertically integrated firms that controlled plant breeding, marketing, and shipping. Guthman refers to this as the Strawberry Squeeze in which growers are caught between high costs of production (about $\$ 68,000$ U.S. per acre per year in 2015) and the prices that the buyers and shippers are willing to pay.

And then comes the unravelling: a shortage of labour due to the United States federal government crackdown on undocumented workers; the emergence of other pathogens in the seriously depleted soil; and a ban on methyl bromide, the cheapest and most effective fumigant, because of its ozone depleting properties. With population growth in the areas around the strawberry fields, no viable alternative to methyl bromide has appeared, often because of concerns about the effects of chemical drift on residents - an issue largely ignored in the case of the migrant labourers who have applied these fumigants for almost a century. To make matters worse, even as methyl bromide was being phased out, plant breeders continued to be complacent and delayed selecting for disease-resistant traits. Drought and extreme weather have increased stressors to the already fragile cultivars, resulting in increased costs and decreased yields. Grower profits fell from an average of $\$ 8,000$ U.S per acre in 2010 to $\$ 2,300$ per acre in 2016 . Wilted paints a picture of an industry that has become a socio-ecological disaster. Yet, while Guthman expertly narrates the historical trajectory and political economy of the strawberry industry she neglects to consider the multiple externalities such as greenhouse gas emissions, water table depletion, plastic waste, and the repair of lifeless and exhausted soils that will eventually be borne by society at large. Her discussion of organic and agroecological practices is limited and ultimately assessed as "not a replicable model for the larger strawberry industry, not in this ecology, not in this economy" (p. 204). Furthermore, she entertains a number of unsustainable alternative practices such as the use of coir or peat based soilless systems and 'anaerobic soil disinfestation' whereby fields are flooded with water and injected with a carbon source such as rice bran or molasses. 
Guthman's begrudging acceptance of the status quo as lacking a viable alternative reflects both a lost opportunity and a lack of vision that undermines the potential of this book. There are too many places where Guthman sits on the fence, acknowledging the myriad of social and environmental harms while defending the need for consumers to have year-round access to "abundant, healthy and affordable strawberries" (p. 197). There are no easy answers, but surely we need to acknowledge the ecological limits of our planet for growing food. A truly healthy strawberry must be one that is grown fairly and sustainably. We can be innovative and bold and search for real solutions. All of us - consumers, farmers and industry - can change the way we think about food and farming and profit; many would argue that if we don't do it soon, ecological collapse will be the very painful ending to this tale.

Janette Haase worked for many years as an organic market gardener. She is the author of From Seed to Table (Insomniac Press, 2009) and has facilitated many school and community garden projects in the Kingston area. She is currently completing her M.Sc. at Queen's University researching school garden programs. She lives on Wolfe Island near Kingston. 